\title{
Relationships between digital maturity, organizational agility, and firm performance: An empirical investigation on SMEs
}

\section{Dijital olgunluk, örgütsel çeviklik ve firma performansı arasındaki ilişkiler: KOBİler üzerine ampirik bir araştırma}

\author{
Büşra Alma Çallı1 \\ Levent Çallı
}

${ }^{1}$ Res. Asst. PhD., Sakarya University,

Sakarya, busraalma@sakarya.edu.tr

ORCID: 0000-0001-7411-4295

2 Asst. Prof., Sakarya University,

Sakarya, lcalli@sakarya.edu.tr

ORCID: 0000-0003-2221-1469

\section{Corresponding Author:}

Levent Çallı, Sakarya University, lcalli@sakarya.edu.tr

\section{Submitted: $28 / 02 / 2021$}

First Revised: 25/03/2021

Second Revised: 14/05/2021

Accepted: 17/05/2021

Online Published: 25/06/2021

Citation: Alma Çallı, B., \& Çallı, L., Relationships between digital maturity, organizational agility, and firm performance: An empirical investigation on SMEs, bmij (2021) 9 (2): 486-502, doi: https://doi.org/10.15295/bmij.v9i2.1786

\begin{abstract}
Digitalization has significant power to boost the performance of small and medium-sized enterprises (SMEs). Most scholars approached the phenomenon from different standpoints by examining the effects of information technology skills, digital skills, information systems capabilities, information and communication technologies (ICT) adoption, and digitalization on firm performance. However, although the terms are interrelated, the impact of digital maturity on SMEs' performance has been rarely investigated. Digital maturity examines the extent of digitalization and digital capabilities of organizations, which is essential in evaluating state-of-the-art organizations' digitalization efforts and providing a roadmap for further improvement. Although digitalization offers various benefits to organizations, its direct effect on the performance outcome is still arguable. Prior studies had revealed mixed findings when they assessed the impact of digital maturity on firm performance. Hence, some studies called for research for the examination of possible intervening variables.

Consequently, this study examines the effects of digital maturity and organizational agility on firm performance. Furthermore, the moderating role of organizational agility in the digital maturity-firm performance link is also investigated. Data for testing the proposed model was collected from SMEs in the Marmara Region of Turkey using a convenience sampling technique. The structural equation modeling with partial least squares estimation (PLS-SEM) approach was used to analyze 119 responses collected from SMEs via face-to-face and online questionnaires. Eighty-two of the respondents identified themselves as entrepreneurs/partners. 13 respondents are senior executives, 14 are mid-level managers, 8 are white-collar employees, and two stated that they work in different positions than these. The findings show that organizational agility and digital maturity have a positive impact on firm performance. However, when the role of organizational agility is examined as a moderator, it is discovered that the factor reduces the effect of digital maturity on firm performance.
\end{abstract}

Keywords: Digital maturity, SMEs, Organizational Agility, Firm Performance, SEM, PLS

Jel Codes: M10, M14, M15

Öz

Dijitalleşme, küçük ve orta ölçekli işletmelerin (KOBI'ler) performansını artıracak önemli bir güce sahiptir. Mevcut çalışmalar, bilgi teknolojisi becerileri, dijital beceriler, bilişim sistemleriyle ilgili yetenekler, bilgi ve iletişim teknolojilerinin (BIT) benimsenmesi ve dijitalleşmenin firma performansı üzerindeki etkilerini inceleyerek konuya farklı bakış açılarından yaklaşmıştır. Bu terimler birbirleriyle ilişkili olmasına ve araştırmacılar tarafından birbirleri yerine kullanılmasına rağmen, dijital olgunluğun KOBİ performansı üzerindeki etkisi nadiren araştırılmıştır. Dijital olgunluk modelleri, işletmelerin dijitalleşme çabalarını değerlendirmek ve daha fazla iyileştirme sağlamak için işletmelerin dijitalleşen süreçlerinin, iş modellerinin ve dijital yeteneklerinin kapsamını incelemektedir. Dijitalleşme kuruluşlara çeşitli faydalar sağlasa da performans üzerine olan direkt etkisi hala tartışılmaktadır. Literatürde, dijital olgunluğun firma performansı üzerindeki etkisini değerlendiren çalışmalar farklı faktörlerin dijitalleşme ve performans ilişkisinin üzerinde etkisi olduğu ifade etmektedir. Bu bağlamda, bu çalışma dijital olgunluk-firma performansı ilişkisinde örgütsel çeviklik değişkeninin düzenleyici etkisini dikkate alarak incelemektedir. Araştırma kapsamında geliştirilen kavramsal modelin test edilmesi için Marmara Bölgesi'ndeki KOBİ'lerden yüz yüze ve çevrimiçi anket yöntemiyle toplanan 119 veri Kısmi En Küçük Kareler Yapısal Eşitlik Modellemesiyle (KEK-YEM) analiz edilmiştir. Ankete katılanlardan 82'si kendilerini girişimci / ortak olarak tanımlamıştır. Katılımcılardan 13'ü üst düzey yönetici, 14'ü orta kademe yönetici, 8'i beyaz yakalı, 2'si ise ifade edilen bu pozisyonlardan farklı bir statüde çalıştıklarını belirtmiştir. Bulgular dijital olgunluk ve örgütsel çevikliğin performans üzerinde pozitif bir etkiye sahip olduğunu ortaya koymaktadır. Örgütsel çevikliğin düzenleyici etkisi incelendiğinde, faktörün dijital olgunluğun performans üzerindeki etkisini azalttığı saptanmıştır. Dijital olgunluğun performans üzerindeki artırıcı etkisini ampirik olarak ortaya koymak işletmelerin bilişim algısını geliştireceği, böylece dijitalleşmeyle ilgili faydaların algılanarak gerekli adımların atılması ve kaynakların ayrılmasında etkili olabileceği düşünülmektedir.

Anahtar Kelimeler: Dijital olgunluk, KOBİ, Organizasyonel Çeviklik, Firma Performansı, SEM, PLS

JEL Kodları: M10, M14, M15 


\section{Introduction}

Today's organizations face numerous challenges, such as the demand for highly customized products/services, effective business processes, and high-performing supply chains. Hence, digitization has become a necessary capability of an organization to cope with these challenges (Blatz, Bulander, \& Dietel, 2018). The digital world compels organizations to achieve digital transformation to be competitive. Digitally mature organizations benefit from higher profitability and revenue enhancement more than low-mature organizations (Jafvert \& Gustafsson, 2019). Organizations' competitiveness depends on their innovation capabilities and their success in offering value-added products and services for customers. Customer requirements and the necessity for the rapid adoption of new requirements through organizational assets are the major drivers of digitalization (Dombrowski \& Ritcher, 2018). Ghobakhloo and Ching (2019) stated that digital technologies offer performance enhancement through contributing sales improvement, providing effectiveness in customer and supplier relationships, and promoting the organization's capabilities.

Small and medium-sized enterprises (SMEs) are considered the main building blocks of the economy in most European countries ( Muller et al., 2019). For instance, Annual Report on European SMEs 2018/2019 shows that there were slightly more than 25 million SMEs in the EU-28, and $99.8 \%$ of enterprises in the non-financial business sector (NFBS) are SMEs. These SMEs are producing $56.4 \%$ of NFBS value and $66.6 \%$ of NFBS employment (Muller et al., 2019). According to the Turkish Statistical Institute (2019), the percentage of SMEs in Turkey is almost $99.8 \%$, and with more than $72.4 \%$ of employment, they significantly contribute to the economy and revenue generation (TÜIK, 2019a). Unfortunately, most of these enterprises, which have tremendous potential for improving the economy, have not yet fully achieved digitalization today. For instance, only $20.5 \%$ of Turkish enterprises with ten or more employees use Enterprise Resource Planning (ERP) software, and only 18.5\% of them use a Customer Relationship Management (CRM) system. Moreover, only $13.7 \%$ of them provide employment opportunities for ICT specialists (TÜİK, 2019b). In this respect, the digitization level of Turkish SMEs is not adequate. In most European countries, a similar situation is also observed. For example, the ICT specialist employment rate is $15 \%$ in small enterprises, and the rate of using ERP software is 33\% in SMEs. Furthermore, there is a substantial digital gap between the countries of the European Union. For instance, while the cloud computing usage rate is 50\% in Finland, it is below 10\% in Bulgaria, Greece, Romania, and for all sizes of enterprises, it is $14.1 \%$ in Turkey (European Commission, 2020; TÜİK, 2020).

Because of the unique nature of SMEs, their adoption of digital technologies is different compared to larger organizations as they possess limited resources, and digitalization is challenging, especially for SMEs in developing countries (Ghobakhloo \& Ching, 2019). Developing countries have always sought to establish funding services that will provide financial support to domestic SMEs because of their vital role in the overall employment and mutual benefit ecosystem formed with large-scale enterprises via supply chain systems. As a result, a large organization, even though digitalized by itself but relying on a non-digitized supply chain system, would be dramatically weakened in the long run when faced with equally large businesses benefiting from a completely digitalized supply chain (Bokša, Šaroch, \& Bokšová, 2020).

SMEs need to collaborate and coordinate with enterprise partners since they are always part of a broader value chain. Financial and human capital, however, are almost always scarce. It is, therefore, important to have a precise understanding of the stages of digital transformation (Blatz et al., 2018).

Regardless of the economic value of SMEs, little is documented about the antecedents, implications, and difficulties of SMEs' digitization (Eller, Alford, Kallmünzer, \& Peters, 2020). Prior studies have mainly investigated the effects of technology orientation, IT skills, or specific digital capabilities on firm performance; however, little research examining the digital maturity of SMEs and its link with firm performance is available. Limited findings of those studies have revealed inconsistent results regarding the effect of digital maturity. For instance, according to Wroblewski (2018) performance of digitally mature organizations is not higher than their peers'.

For this reason, the primary goal of this study is to reveal the effect of digital maturity on the performance of SMEs. It is believed that providing insight and knowledge to managers, specifically in digitally low-mature organizations, is essential. Another goal is to investigate the moderator effect of organizational agility in the digital maturity-performance link as mixed findings of previous studies point out that there may be different variables that affect this relationship. 
Creating awareness regarding the performance outcomes of higher digital maturity is believed to be a significant element providing progress in digital transformation and attaining competitiveness. Therefore, it is important to understand the link between their digital maturity and performance to maintain a productive digital transformation process and increase perceptions regarding the significance of digital transformation. It is vital to establish a new digital strategy, redefine business goals, and evaluate new digital business models.

\section{Literature review}

\section{Digitization-digitalization-digital transformation}

According to Haffke, Kalgovas, and Benlian (2016), digitization initiatives of organizations stem from functional areas encompassing sales \& marketing, operations, or customer services. Lately, digital initiatives have become wider, intending to achieve a revenue-driving way to the market. The digital realm of enterprises is no longer limited to communication mechanisms, and considerable importance is attained in digital activities. Although digitization, digitalization, and digital transformation are used interchangeably, they are not completely interchangeable (Haffke et al., 2016; Jafvert \& Gustafsson, 2019).

Gartner (2020) defines digitization as converting the analog process to the digital without altering the structure of the process, while digitalization requires changing the business processes using digital technologies. Accordingly, digitalization encompasses the processes of shifting to digital business. Regarding the digital transformation, Savic (2019) defines the concept as the use of existing knowledge to thoroughly change the nature of the organization, including its culture, operational configuration, technology, and strategies. Digital transformation necessitates a thorough revision of the way of how technology is used in an organization. Hence, digital transformation refers to integrating a series of digitization initiatives into all aspects of the business and essentially transforming the business's operations, as cited in Jafvert and Gustafsson (2019). As reported by McKinsey, digital transformation means the reorganization of business models, technology, and processes for creating new value with adapting to the pace of constantly changing technology (Ulas, 2019).

\section{Digital maturity-agility-performance}

Becker, Knackstedt, and Pöppelbuß (2009) stated that maturity models enable evaluation of the existing situation of an organization, determination of improvement objectives by providing a roadmap for digital transformation (North, Aramburu, Lorenzo, \& Rego, 2019). Maturity models serve as a measure for assessing organizational capabilities required to achieve digital transformation (North et al., 2019). Maturity models have become a common instrument depending on how they assess and reveal an organization's basic digital maturity level. Assessment of the current and future digital transformation requirements substantially depends on this information (Williams, Schallmo, Lang, \& Boardman, 2019).

According to Kohli and Grover (2008), agility is one of the capabilities necessary for market competition. Digital capabilities are vital for new product development and innovation and the adoption of new technologies. In this sense, agility is a capability encompassing flexibility, fast execution of operational changes, and digitization of processes. Thus, agility is a capability supporting digital capabilities, which facilitate responding to new digital technologies. As a result, agility contributes to enhancing digital business performance (Freitas Junior, Gastaud Maçada, Brinkhues, \& Montesdioca, 2016). Zhou and Wu (2010) explored strategic flexibility increases the positive influence of technological capability on innovation. According to Ravichandran (2018), digital platform capabilities facilitate further digitization and enable the adoption of emerging technologies effectively. Digital platforms enhance the ability to both watch market trends and respond to changing customer demands quickly. Sanchez (1995) stated that digital platforms increase the inherent ability to use organizational resources flexibly, and resources might be utilized in new ways to provide market responsiveness. Supporting this idea, Ravichandran (2018) explored that organizational agility had a positive link with performance and digital platform capabilities.

Eller et al. (2020) explored that digitalization significantly impacted performance and mediated the information technology-performance link. According to Eller et al. (2020), information and communication technologies facilitate handling consumer interactions through social media, which positively affects the financial success of small and medium-sized businesses because of the elimination of advertisement expenses and strong customer relations. Niemand, Rigtering, Kallmünzer, Kraus, and Maalaoui (2020) investigated the effect of strategic vision on the level of digitalization and explored that technology is not adequate at boosting a bank's performance. On the other hand, combining the strategic vision with entrepreneurial ability provides to get benefit from digitalization. Al-Ansari, Altalib, and 
Sardoh (2013) investigated the effect of technology orientation on innovation and firm performance in SMEs in Dubai. Technology orientation was found significantly linked with innovativeness, and innovativeness had a significant effect on firm performance. Technology orientation's impact on the firm performance was weak, and the relationship between technology orientation and performance was mediated through innovation.

According to Levallet and Chan (2018), digital capabilities, specifically flexible IT infrastructure and information management capability, can enhance the capability of managers to behave quickly and improvise. Nevertheless, these digital capabilities were found necessary but not adequate for successful managerial improvisation. A culture promoting innovation and a flexible organizational structure was also suggested. Ekuobase and Olutayo (2016) also found a negative and weak relationship between information and communication technology (ICT) maturity and ICT value. The authors pointed out that getting benefits from ICT adoption is not always related to the extent of ICT adoption, and there may be other factors affecting this relationship.

COVID-19 is a public health issue that has raised significant challenges to the sustainability and development of SMEs. The crisis also emphasized the essential role of information and communication technologies in reacting to the outbreak of COVID-19 (Guo, Yang, Huang, \& Guo, 2020). Guo et al. (2020) examined the relationship between digitalization, public crisis response, and SME performance. Their findings revealed that the SME's efforts to digitalize, through their degree of digitalization, digital technology adoption, and business model, aid in overcoming public crises. Furthermore, digitalization leads to enhancing the performance of SMEs through the development of response strategies.

Khin and Ho (2019) discovered that an organization's digital orientation and capability positively impacted its capability to innovate digitally, and digital innovation mediated the influence of digital capability and technology orientation on firm performance. Tariq, Mad Lazim, and Iteng (2019) explored that technology orientation moderated the relationship between product, process innovation, organizational learning capabilities, and SME performance. However, Wroblewski (2018) did not find empirical support for the relationship between digital maturity and firm performance. Moreover, prior findings regarding the positive effect of technical IT capabilities on organizational agility are inconsistent. Organizations that achieved agility might demonstrate considerable differences in terms of their digitalization practices. For instance, Carrefour demonstrated agility as high as Walmart in China and did not adopt advanced digital technologies (Gao, Zhang, Gong, \& Li, 2020).

Gao, Zhang, Gong, and Li (2020) found that technical IT capabilities, including flexibility and integration, positively impacted agility. Additionally, they explored that IT business spanning capability demonstrated mixed results regarding the relationship between technical IT capabilities and agility. A critical finding of the study indicated "a negative synergy or substitution relationship between IT business spanning capability and IT integration with regard to organizational agility" (Gao et al., 2020, p. 953). Besides, Rettig (2007) found a negative impact of IT capability on organizational agility.

To the best of our knowledge, there are almost no empirical studies examining the link between digital maturity and performance for Turkey context. Existing studies are generally in the form literature review or conceptual discussions focusing on digital maturity, Industry 4.0 maturity, or digital transformation (Baki \& Serdar, 2020b; Nuroğlu \& Nuroğlu, 2018; Özmen, Eriş, \& Süral, 2020; Pakdemirli, 2019; Sağbaş \& Gülseren, 2019; Yıldırım, 2020) and some researches have concentrated on to determine the digital maturity or Industry 4.0 maturity level of organizations (Baki \& Serdar, 2020a; Büyüközkan \& Güler, 2020; Özçelik, Erkollar, \& Cebeci, 2018; Ustaoğlu, 2019; Yiğitol, Güleş, \& Sarı, 2020).

Among other studies, İmamoğlu, İnce, and Türkcan (2021) have conceptually discussed the Industry 4.0 applications, which emerged as a strategic initiative based on the digitalization of production systems (Rojko, 2017) and the impact of these applications on organizational agility. İmamoğlu et al. (2021) stated that organizational agility provides firms to stay informed about market trends and innovations and act quickly. Firms have begun a digital transformation due to Industry 4.0 deployments, which facilitate being proactive in the turbulent and competitive environment. Hence, it can be expected that Industry 4.0 implementations play a significant role in increasing organizational agility. Ustasüleyman (2008) aimed to examine the impact of competitive capacity and agility drivers on business performance. The effect of competitive capacity on agility capacity was also analyzed. Data for testing the proposed hypotheses were collected from 500 large enterprises registered in the Istanbul Chamber of Industry, using a questionnaire survey. Findings revealed that agility drivers had a significant effect on business performance. It was also explored that competitive capacity significantly impacted agility capacity (Ustasüleyman, 2008). 
Akkaya and Tabak (2018) developed the Turkish version of the organizational agility scale of Sharifi and Zhang (1999). Işık (2020) investigated the social capital effect on strategic agility. A survey of 38 SMEs in Bitlis was performed to collect the data. The analysis results showed that the dimensions of social capital (structural, relational, and cognitive) positively impact the dimensions of strategic agility (technology capability, organizational learning, collaborative innovation, and internal alignment). Çetinkaya and Akkoca (2021) focused on the examination of the mediating effect of organizational communication on the link between strategic leadership and organizational agility. 482 employees working for various private sectors in Kırşehir were surveyed. A positive and significant association between strategic leadership and organizational agility was revealed based on the study findings. The mediating effect of organizational communication was also confirmed. Concentrating on the service sector, Özeroğlu (2019) examined the influence of visionary leadership on organizational agility. Data were collected from healthcare personal in private hospitals in Beylikdüzü, İstanbul. Regarding the study's findings, it was explored that dimensions of visionary leadership had a significant impact on organizational agility. The study of Akkaya et al. (2019) investigated the effect of dynamic capabilities of managers in the manufacturing sector on organizational agility. It was explored that reconfiguration, sensing, and seizing dimensions of dynamic capabilities significantly influenced the organizational agility of enterprises. Regarding the SME context, Koçyiğit and Akkaya (2020) explored that the flexibility of the organizational structure positively and significantly impacted organizational agility. Specifically, agility capabilities comprising speed, competency, responsiveness, and flexibility were affected by organizational flexibility.

Sağır and Gönülölmez (2019) examined the impact of structural capital, including intellectual capital, organizational culture, and information systems on operational efficiency. The intermediary role of organizational agility was also analyzed. Findings revealed that structural capital had an effect on the performance, and the intermediary role of organizational agility was confirmed. Eryılmaz (2020) proposed that as the organization's digitalization increases, the organization's agility will also increase. However, the study did not empirically confirm this hypothesis. Sağbaş and İnce (2015) specifically focused on supply chain practices. The impacts of information technologies and their integration on firm performance and agility were investigated. It was discovered that both integration and information technologies affected performance and agility. Organizational agility had an effect on competitive advantage, according to Coşkun (2019). The research of Uğurlu, Çolakoğlu, and Öztosun (2019), which focused on manufacturing firms operating in Gaziantep in Turkey, revealed the significant impact of strategic agility on firm performance.

Consequently, based on the arguments and research gaps discovered from the literature, the following research model is proposed.

a-Normal

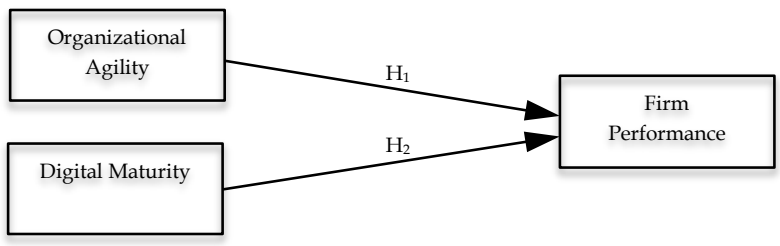

\section{b-With Moderation Effect}

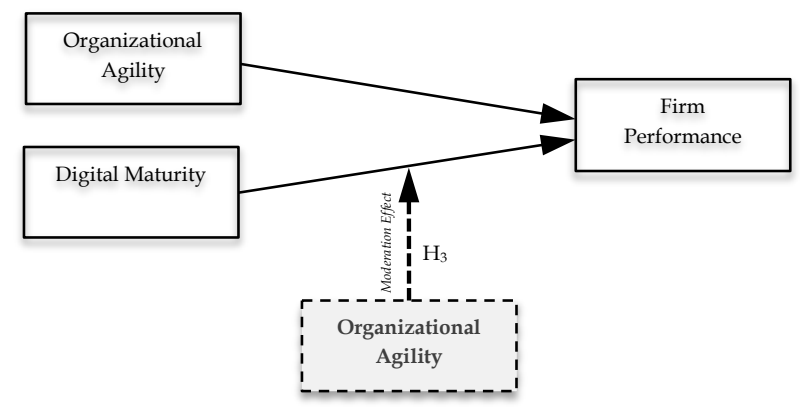

Figure 1: Research Model

The research model in Figure 1 represents that digital maturity positively influences firm performance. Organizational agility is posited to directly influence and moderate the impact of digital maturity on firm performance.

$\mathrm{H}_{1}$ : Organizational Agility positively impacts Firm Performance.

$\mathrm{H}_{2}$ : Digital Maturity positively impacts Firm Performance.

$\mathrm{H}_{3}$ : Organizational Agility moderates the relationship between Digital Maturity and Firm Performance. 


\section{Method}

\section{Sample and data collection}

Data for testing the proposed model was collected from SMEs in the Marmara Region of Turkey using a convenience sampling technique in the last quarter of 2019. Every firm compatible with the SMEs definition in Turkey was considered as a sample source. Both face-to-face and online survey methods were utilized for gathering data from SMEs. Among $160(=\mathrm{N})$ distributed questionnaires, 119 answers were received, representing a response rate of $74.4 \%$.

\section{Descriptive statistics}

Table 1 illustrates the demographic details of the participants in this research. $88 \%$ of the respondents are male, and $51 \%$ are between the ages of 30 and 47 . Besides, $69 \%$ of the respondents define themselves as either owners or partners of the enterprise. In terms of education level, $57 \%$ of the participants have a university degree.

Table 1: Sample Demographics

\begin{tabular}{|c|c|c|c|c|c|c|c|}
\hline \multirow{2}{*}{ Status } & \multirow{2}{*}{ Age } & \multicolumn{2}{|c|}{ University } & \multicolumn{2}{|c|}{ High School } & \multirow{2}{*}{$\begin{array}{c}\text { Primary school } \\
\text { Male }\end{array}$} & \multirow{2}{*}{ Total } \\
\hline & & Male & Female & Male & Female & & \\
\hline \multirow{6}{*}{ Entrepreneur / Partner } & $18-23$ & 7 & & 2 & & & 9 \\
\hline & $24-29$ & 2 & & 1 & & & 3 \\
\hline & $30-35$ & 5 & 1 & & & 1 & 7 \\
\hline & $36-41$ & 3 & 1 & 3 & 1 & 3 & 11 \\
\hline & $42-47$ & 9 & 1 & 9 & & 3 & 22 \\
\hline & $48+$ & 10 & & 12 & & 8 & 30 \\
\hline \multirow{3}{*}{ Senior Executive } & 24-29 & 1 & & & & & 1 \\
\hline & $36-41$ & 5 & 4 & & & 1 & 10 \\
\hline & $42-47$ & 1 & & 1 & & & 2 \\
\hline \multirow{5}{*}{ Mid-level manager } & $18-23$ & & & 1 & & & 1 \\
\hline & $24-29$ & 1 & 3 & 2 & & & 6 \\
\hline & $30-35$ & 3 & & 1 & & & 4 \\
\hline & $36-41$ & 1 & & & & & 1 \\
\hline & $48+$ & 1 & & & & 1 & 2 \\
\hline \multirow{3}{*}{ White-collar employee } & $18-23$ & 1 & & & & & 1 \\
\hline & 24-29 & & 3 & & & & 3 \\
\hline & $30-35$ & 4 & & & & & 4 \\
\hline \multirow{2}{*}{ Other } & $18-23$ & 1 & & & & & 1 \\
\hline & 24-29 & 1 & & & & & 1 \\
\hline \multicolumn{2}{|l|}{ Total } & 55 & 13 & 32 & 1 & 17 & 119 \\
\hline
\end{tabular}

Table 2 shows the sectoral distribution of the enterprises in which the research participant is involved. $60 \%$ of the businesses operating in 19 different sectors are family businesses. 
Table 2: Distribution of Family and Non-Family Businesses by Industry

\begin{tabular}{|l|c|c|c|}
\hline \multirow{2}{*}{ Business Industry } & \multicolumn{2}{|l|}{ Family Business } & \multirow{2}{*}{ Total } \\
\cline { 2 - 3 } & Yes & No & \\
\hline Trade (Sales and marketing) & 16 & 4 & 20 \\
\hline Metal & 10 & 3 & 13 \\
\hline Woodworks, paper, and paper products & 7 & 4 & 11 \\
\hline Food & 6 & 8 & 14 \\
\hline Glass, cement, and soil & 6 & 3 & 9 \\
\hline Textiles, clothing and leather & 4 & 3 & 7 \\
\hline Construction & 4 & 3 & 7 \\
\hline Automotive & 3 & 2 & 5 \\
\hline Electrical \& Electronics & 3 & 3 & 6 \\
\hline Transportation, logistics, and communication & 2 & 1 & 3 \\
\hline Media, communication, publishing & 2 & & 2 \\
\hline Chemistry, oil, rubber, and plastic & 2 & 2 & 4 \\
\hline Environment & 2 & 2 & 4 \\
\hline Agriculture, hunting and fishing & 1 & & 1 \\
\hline Mining & 1 & 1 & 2 \\
\hline Information \& communication technologies & 1 & 4 & 5 \\
\hline Justice and security & 1 & & 1 \\
\hline Tourism, accommodation, food and beverage services & & 4 & 4 \\
\hline Health and social services & & 1 & 1 \\
\hline Total & $\mathbf{7 1}$ & $\mathbf{4 8}$ & $\mathbf{1 1 9}$ \\
\hline
\end{tabular}

Trade (sales and marketing), metal woodworks, paper, paper products, and food are the industries of $49 \%$ of the total sample.

Table 3: Number of Employees by Industry

\begin{tabular}{|l|c|}
\hline Sector & Number of Employees \\
\hline Metal & 35 \\
\hline Food & 30 \\
\hline Trade (Sales and marketing) & 30 \\
\hline Glass, cement, and soil & 26 \\
\hline Textiles, clothing, and leather & 26 \\
\hline Woodworks, paper, and paper products & 25 \\
\hline Chemistry, oil, rubber, and plastic & 17 \\
\hline Tourism, accommodation, food and beverage services & 17 \\
\hline Electrical \& Electronics & 16 \\
\hline Automotive & 16 \\
\hline Environment & 15 \\
\hline Information \& communication technologies & 12 \\
\hline Construction & 11 \\
\hline Transportation, logistics and communication & 7 \\
\hline Mining & 6 \\
\hline Media, communication, publishing & 5 \\
\hline Health and social services & 3 \\
\hline Agriculture, hunting, and fishing & 2 \\
\hline Justice and security & 1 \\
\hline
\end{tabular}

Table 3 shows the number of employees by industry. Metal, food, and trade (sales and marketing) have the highest employment number in all industries.

\section{Measurement scales}

This study utilized scales derived from prior literature. Digital maturity was comprised of three subdimensions, including customer experience, operational processes, and business models. Four items were used as indicators of customer experience, four items for operational processes, and two items for business models, for a total of 10 questions (Jafvert \& Gustafsson, 2019). A total of 16 items demonstrating three subdimensions of customer responsiveness ( 5 items), operational flexibility (6 items), and strategic flexibility (5 items) were adapted from Ravichandran (2018). Ravichandran (2018) stated that the studies conducted by Roberts and Grover (2012), Sambamurthy Bharadwaj and Grover (2003), Mahmood and Soon (1991), and Rindova (2001) were used in the preparation of the scale, respectively. Finally, firm performance was measured with five items from Lonial and Carter (2015). In 
the case of digital maturity, associated variables were rated on a five-point Likert scale ranging from $1=$ "totally disagree" to $5=$ "totally agree". Organizational agility and firm performance were measured with specific items evaluating performance relative to competitors by using a five-point scale offering response choices ranging from $1=$ "clearly poorer" to $5=$ "clearly better". The five-point Likert scale was adopted instead of the original seven-point scale format since it has been shown in the literature to increase the response rate, quality of answers, and less confusing (Babakus \& Mangold, 1992; Bouranta, Chitiris, \& Paravantis, 2009).

\section{Data analysis}

The structural equation modeling with the partial least squares estimation (PLS-SEM) approach was used to test the hypotheses expressed in this research. PLS-SEM, which has been increasingly used in management information systems, marketing, operations management, and other business disciplines, aims to maximize the explained variance of dependent latent structures in a model without assumptions about data distribution (Hair, Ringle, \& Sarstedt, 2011; Hair, Ringle, \& Sarstedt, 2013; Wong, 2013). SmartPLS software was used for reliability and validity analyzes shown in Table 4.

Four main values were considered to measure the reliability of the measurement model. These are; item reliability, Cronbach's Alpha (a), Average Variance Extracted (AVE), and Composite Reliability. For item reliability, Outer Loadings (O.L.) are expected to be greater than 0,7 (Hulland, 1999). Items below certain thresholds were eliminated from the measurement model until the optimum level of reliability value was achieved. Three items from digital maturity, seven items from organizational agility, and one item from firm performance were not considered in the analysis because they did not meet this criterion. As a result, the customer experience sub-factor in the digital maturity, the strategic flexibility, and customer responsiveness sub-factors in the organization agility are represented with one item in the scale. Appendix-1 shows the entire scale in Turkish and English that was used in the research. As seen in Table 4, all loadings fulfill the requirement. a, AVE, and C.R. were considered for the internal consistency reliability of each construct. As seen in Table 4 , the a ( $\geq 0.70)$, C.R. $(\geq 0.70)$, and AVE $(\geq 0.50)$ of each construct are at the accepted level (Bagozzi \& Yi, 1988; Fornell \& Larcker, 1981; Hair, C. Black, Babin, \& Anderson, 2014).

Table 4: Construct Reliability and Validity

\begin{tabular}{|c|c|c|c|c|}
\hline Construct and Items & OL & a & CR & AVE \\
\hline \multicolumn{5}{|l|}{ Digital Maturity - [Mean: 3,31; SD: 1,24] } \\
\hline $\begin{array}{l}\text { DM9 - We use digital technologies to increase the performance or added value of our } \\
\text { existing products and services }\end{array}$ & 0.89 & \multirow{7}{*}{0,90} & \multirow{7}{*}{0,92} & \multirow{7}{*}{0,64} \\
\hline DM10 - We have launched new business models based on digital technologies & 0.87 & & & \\
\hline $\begin{array}{l}\text { DM7 - We have an integrated view of key operational and customer information (integrated } \\
\text { view }=\text { close and seamless coordination between several departments, groups, organizations, } \\
\text { systems) }\end{array}$ & 0.83 & & & \\
\hline DM8 - We use analytics to make better operational decisions & 0,78 & & & \\
\hline $\begin{array}{l}\text { DM5 - Technology is allowing us to link customer-facing and operational processes in new } \\
\text { ways }\end{array}$ & 0.74 & & & \\
\hline $\begin{array}{l}\text { DM1 - We are using digital technologies (such as analytics, social media, mobile, and } \\
\text { embedded devices) to understand our customers better. }\end{array}$ & 0.74 & & & \\
\hline $\begin{array}{l}\text { DM6 - Our core processes are automated (automated= operated largely by automatic } \\
\text { equipment) }\end{array}$ & 0.73 & & & \\
\hline \multicolumn{5}{|l|}{ Organizational Agility - [Mean:3,48; SD: 1,22] } \\
\hline OA7 - We are successfully integrating entire supply chain processes & 0.93 & \multirow{8}{*}{0.96} & \multirow{8}{*}{0.96} & \multirow{8}{*}{0.77} \\
\hline OA10 - We are successful at enhancing the speed of product/service delivery & 0.90 & & & \\
\hline OA6 - We are successful at the integration of internal business processes & 0.90 & & & \\
\hline OA12 - We are successful at enhancing the speed of attempting to opportunities and threats & 0.89 & & & \\
\hline OA11 - We are successful at enhancing the pace of logistic processes & 0.86 & & & \\
\hline OA8 - We are successful at increasing the flexibility of processes & 0.86 & & & \\
\hline OA2 - We are successful at customizing products/services based on customer demands & 0.84 & & & \\
\hline OA9 - We are successful at enhancing the pace of product development & 0.81 & & & \\
\hline \multicolumn{5}{|l|}{ Firm Performance - [Mean: 3,32; SD: 1,09] } \\
\hline P5 - Revenue growth (for the last three years) & 0.93 & \multirow{4}{*}{0.93} & \multirow{4}{*}{0.95} & \multirow{4}{*}{0.83} \\
\hline P4 - Growth of market share (for the last three years) & 0.92 & & & \\
\hline P2 - Growth of cash flow & 0.91 & & & \\
\hline P3 - Growth of profit to revenue ratio & 0.90 & & & \\
\hline
\end{tabular}

OL: Outer Loadings SD: Standard Deviation $\quad$ a: Cronbach's Alpha C.R.: Composite Reliability AVE: Average Variance 
For the discriminant validity of the measurement model, the square root of the AVE of each variable is expected to be larger than the variable correlations (Fornell \& Larcker, 1981; Hair et al., 2014). As seen in Table 5, each value of variables is at the desired level.

Table 5: Discriminant Validity

\begin{tabular}{|l|c|c|c|}
\hline & Digital Maturity & Firm Performance & Organizational Agility \\
\hline Digital Maturity & $\mathbf{0 . 8 0}$ & & \\
\hline Firm Performance & 0.67 & $\mathbf{0 . 9 1}$ & \\
\hline Organizational Agility & 0.60 & 0.72 & $\mathbf{0 . 8 8}$ \\
\hline
\end{tabular}

The square root of AVE values is shown on the diagonal. Other values are the correlations between variables.

The data is not assumed to be normally distributed in the PLS-SEM approach, and the bootstrapping method is using to test the significance of estimated path coefficients and $\mathrm{R}^{2}$. With the bootstrapping method, SmartPLS can produce T-statistics for significant testing of the structural path. In this research, 5,000 bootstrap samples were used as suggested by Hair Jr, Hult, Ringle, and Sarstedt (2016). Analysis results with the bootstrapping method are shown in Table 6 and Table 7.
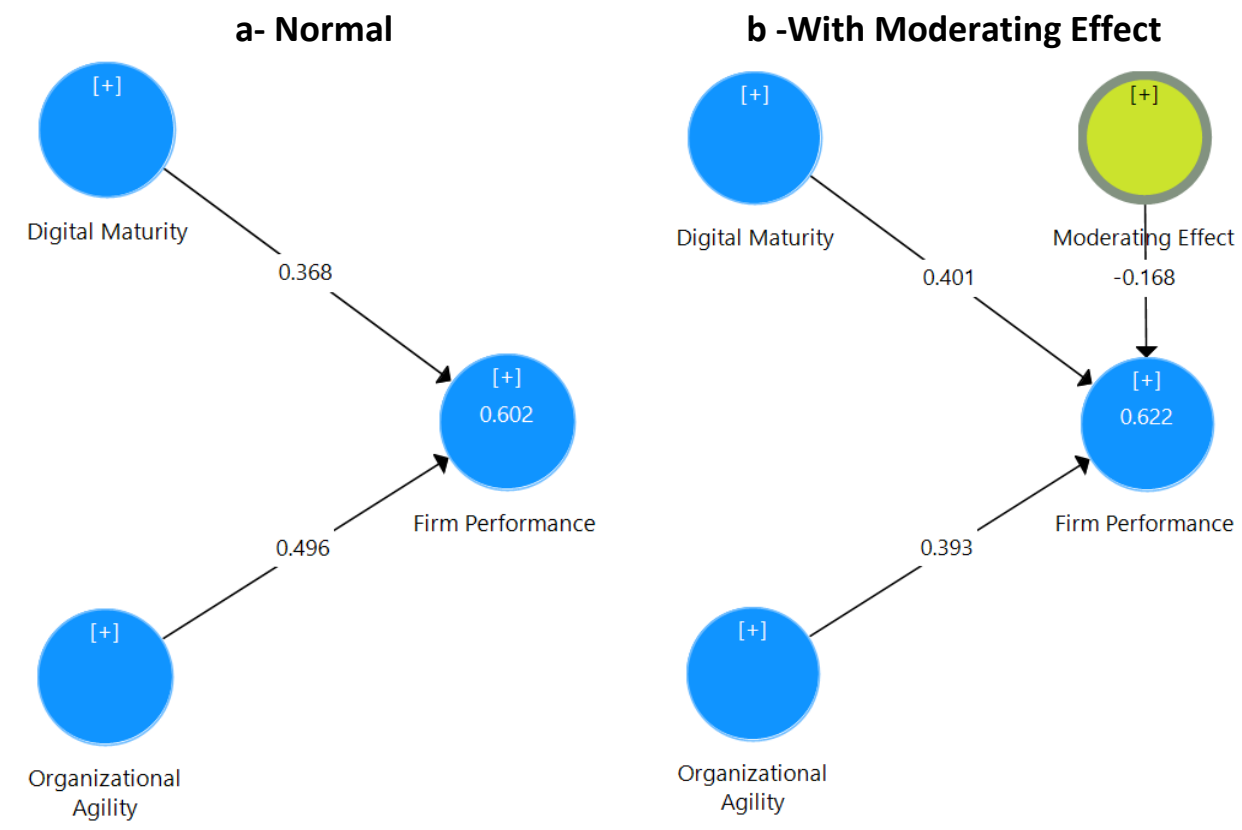

Figure 2: Structural Model

As seen in Table 6, digital maturity (0.368) and organizational agility (0.496) positively impact firm performance. Thus, $\mathrm{H}_{1}$ and $\mathrm{H}_{2}$ hypotheses were both supported $(\mathrm{P}<0.001)$.

Table 6: Normal Model Results

\begin{tabular}{|l|c|c|c|c|c|}
\hline Structural Relation & $\mathbf{f}^{\mathbf{2}}$ & Coefficient & Standard Deviation & T Statistics & P Values \\
\hline Digital Maturity -> Firm Performance & 0.37 & 0.368 & 0.08 & 4,72 & 0.00 \\
\hline Organizational Agility -> Firm Performance & 0.50 & 0.496 & 0.08 & 6,32 & 0.00 \\
\hline
\end{tabular}

These two variables can jointly explain $60 \%$ of the variance of the dependent variable (it is shown inside the blue circle of the firm performance variable in Figure 2a). According to Hair Jr et al. (2016), effect size $\left(\mathrm{f}^{2}\right)$ defines as weak $(\geq 0.02)$, moderate $(\geq 0.15)$, and strong $(\geq 0.35)$, respectively. As seen in $\mathrm{f}^{2}$ values in Table 6, both variables appear to affect firm performance strongly.

Table 7: Model Results with Moderating Effect

\begin{tabular}{|l|c|c|c|c|c|}
\hline Structural Relation & $\mathbf{f}^{\mathbf{2}}$ & Coefficient & Standard Deviation & T Statistics & P Values \\
\hline Digital Maturity -> Firm Performance & 0.26 & 0.401 & 0.07 & 5,54 & 0.00 \\
\hline Moderating Effect -> Firm Performance & 0.05 & -0.168 & 0.08 & 2,09 & 0.04 \\
\hline Organizational Agility -> Firm Performance & 0.20 & 0.393 & 0.10 & 4,18 & 0.00 \\
\hline
\end{tabular}


Table 7 and Figure $2 \mathrm{~b}$ show the moderating effect of organizational agility on the relationship between digital maturity and firm performance. As seen in Table 7, this effect is significant $(P<0.05)$ but weak $\left(\mathrm{f}^{2}=0.05\right)$. Thus, the $\mathrm{H}_{3}$ hypothesis has been supported. This weak effect is seen in Simple Slope Analysis (Figure 3) with detail for better understood.

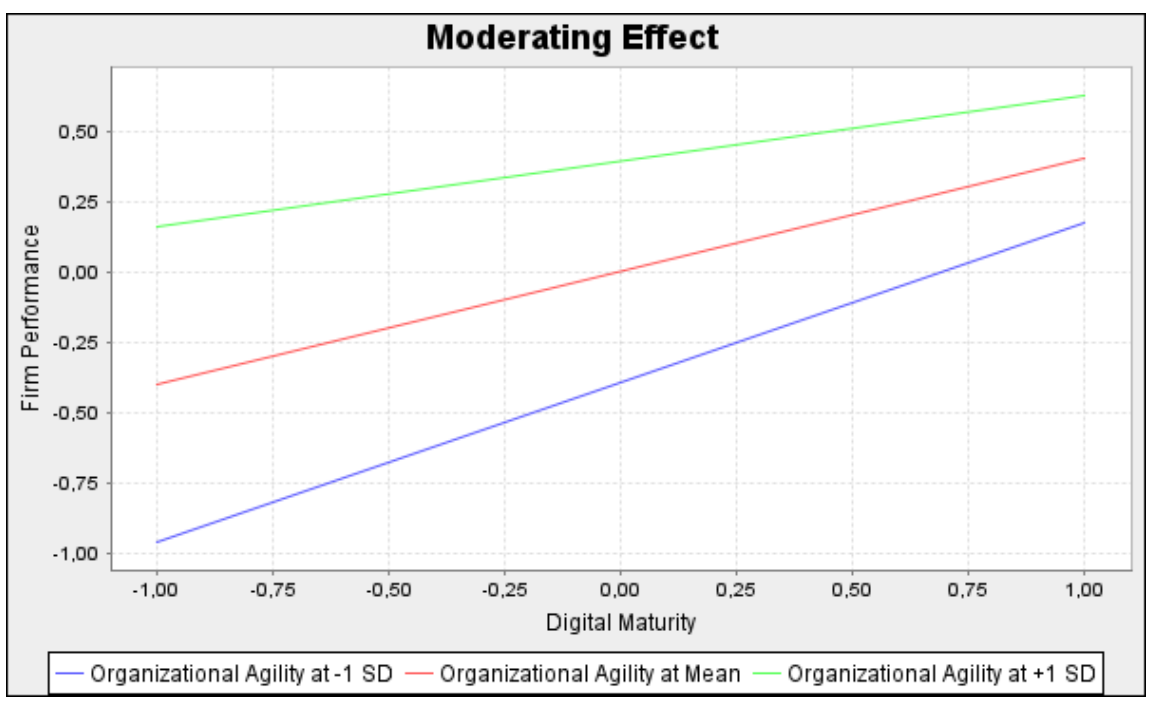

Figure 3: Simple Slope Analysis

Organizational agility is evaluated in three different situations with simple slope analysis. When organizational agility is high (green line), the effect of digital maturity on firm performance is modest. However, this impact is relatively higher when organizational agility is low (blue line).

\section{Conclusion}

The digital maturity level of SMEs is expected to be a considerable competency for enhancing organizational performance by enabling organizations to respond to opportunities and threats quickly. The findings of this study provided support for the enabling role of digital maturity and organizational agility in increasing firm performance. We found strong support for the positive impact of digital maturity on firm performance like research outcomes of (Guo et al., 2020; Zhou \& Wu, 2010). On the contrary, Niemand et al. (2020) revealed that technology is not enough for performance enhancement, and it should be combined with strategic vision and entrepreneurial ability to benefit. The study of Ekuobase and Olutayo (2015) also supported this argument. The authors stated that getting benefits from ICT adoption is not always related to the extent of ICT adoption.

Additionally, Wroblewski (2018) did not explore the significant influence of digital maturity on firm performance, and Al-Ansari et al. (2013) found a weak impact of technology orientation on firm performance. In the Turkey context, Ustasüleyman (2008) found that agility drivers, including changes in information technologies, positively impacted business performance. However, that study investigated large enterprises.

Examining the studies on the subject which have been performed in Turkey, it was discovered that the concept of digital maturity is a fairly new research topic. Different variables related to digital maturity, their predecessors, and consequences have not been investigated. SMEs, which contribute greatly to Turkey's economy, have been examined in a few studies. Among the digital maturity studies, those that focus on determining the digital maturity level have generally tried to determine the current maturity levels of enterprises. Some other studies are in the form of literature review and conceptual discussion. There are also studies focusing on digitalization, digital transformation, or Industry 4.0, but few empirical studies are among them. However, literature findings represent that even the effect of digital maturity on performance is controversial. It is necessary to investigate the factors affecting digital maturity in businesses and their consequences. In this context, the finding of this study identifying the positive effect of digital maturity on the performance of SMEs is an original contribution to the existing literature.

Furthermore, results supported the moderating role of organizational agility in the digital maturityfirm performance link. However, this was a relatively weak effect, and it was discovered that increases in organizational agility decrease the impact of digital maturity on firm performance. These findings represent that organizational agility can differently affect firm performance depending on its interaction with the digital maturity level. The impact of digital maturity of performance diminishes in the presence 
of a high level of organizational agility. Previous studies discovered contradictory results regarding the link between IT capabilities and organizational agility. Although managerial IT skills generally increase the effectiveness of technical IT skills on organizational agility, managerial capabilities might diminish organizational agility (Gao et al., 2020). Digital maturity was measured using three subdimensions, including customer experience, operational processes, and business models in this study. Hence, not including managerial IT capabilities or strategic aspects of digital maturity might have caused the present results.

Opposed to the mixed findings of Gao et al. (2020), Sanchez (1995) explored digital platforms enhance flexibility and market responsiveness. Ravichandran (2018) also found support for the same argument. These findings also empirically confirm the study of İmamoğlu et al. (2021), who conceptually suggested that Industry 4.0 applications will increase organizational agility. Similarly, Eryılmaz (2020) proposed that the extent of digitalization enhances the agility of the business processes. However, the study did not test this hypothesis. Hence, we have limited information regarding the link between digital maturity or digitalization and agility within the Turkey context. Focusing specifically on supply chain applications, the study of M. Sağbaş and İnce (2015) concluded that integration and IT positively affect performance and agility. However, the findings are not comparable to the results of our study, as the study focuses both on supply chain applications specifically and on medium and large-scale Turkish firms.

Ravichandran (2018) discovered that organizational agility positively impacted firm performance regarding the link between agility and performance. Among studies conducted within the Turkey context, Sağır and Gönülölmez (2019) explored that structural capital, including information systems, both increased performance and organizational agility. Further, like our study, the positive impact of agility on firm performance was discovered. Coşkun (2019) discovered that organizational agility had an impact on competitive advantage. However, in the study, detailed information regarding the sample of the study is missing. The survey was employed on white-collar employees in the information and communication technologies sector. Again from studies that focus on Turkey and strategic agility, the study of Uğurlu et al. (2019) revealed the effect of strategic agility on performance. Among the studies in the local literature, the scarcity of studies evaluating the impact of organizational agility on performance in the context of SMEs draws attention. Although the performance impact of supply chain agility has been studied relatively more, strategic and organizational agility has been investigated in terms of performance impact in a limited number of studies. These constraints of the local literature reveal the need for new research to investigate these areas, especially for SMEs. The findings of the study are generally consistent with the international literature. Differences and contradictions are thought to be contextual. It is, therefore important to apply different research designs by including both similar and different variables.

Consequently, this study contributes to the literature by revealing that the combined effects of digital maturity and organizational agility might impede the impact of digital maturity on firm performance. Managerial and strategic aspects of digital maturity might be integrated and examined by future studies for making complete interpretations and anticipating the main effect. Furthermore, a high level of organizational agility is not needed to enhance the impact of digital maturity on firm performance. Organizations that demonstrate a higher level of agility might ignore essential elements of digitalization.

This study has some important managerial implications. First, SMEs should be aware of their existing digitalization practices, capabilities, and the positive impact of their digitalization efforts on firm performance. Many companies are not investing in digital technologies and business models probably because of the lack of awareness regarding the performance outcomes of digitalization. They should focus on the adoption of advanced technologies to boost their performance. In addition to the adoption of technology and business models, embracing a digital mindset and continuous growth strategy is critically important in digital transformation. By providing empirical evidence for policymakers, this study also highlights the importance of allocating resources for the digitalization of SMEs. Governments may consider investing more in increasing the awareness of SMEs in terms of building up digital capabilities and adopting digital technologies.

\section{Limitations and future research}

Although the research findings contribute to the relevant field, some limitations might be addressed by future studies. First of all, collecting data with a convenience sampling method negatively affects the representation ability and generalization of the results. Furthermore, the data obtained from various sectors reveal a more general outcome than the data collected from one specific sector. The evaluation 
of different sectors with a relatively small sample size within the scope of the research may be the reason why items, especially in the organizational agility dimension, did not achieve the desired level of reliability and were excluded from the measurement model. In this sense, future studies should focus on sector-specific and use probabilistic sampling methods to collect data for more efficient results.

Items that fell below certain thresholds were eliminated from the measurement model until the desired level of reliability value was achieved. Hence, the items extracted from the measurement model might have caused improper understanding of respondents. This is an emerging field of study in Turkey, and empirical studies on this topic are very scarce. Hence, future studies addressing these issues are thought to be very important in testing the validity of the adapted scale in this research.

Additionally, aggregated effects of customer experience, operational processes, customer sensitivity, operational flexibility, and strategic flexibility dimensions were considered in this study. Future studies might concentrate on analyzing the independent effects of sub-dimensions of organizational agility and digital maturity.

Other limitations that prevent achieving a larger sample size for this study are time and budget constraints. This research was carried out without any financial support. The data were primarily collected with traditional methods by visiting organized industrial zones since the respondents could not spare time for an online survey. Finding financial support from various institutions and using the online survey method will make it possible to reach a larger sample for future studies.

\section{Peer-review:}

Externally peer-reviewed

\section{Conflict of interests:}

The author(s) has (have) no conflict of interest to declare.

\section{Grant Support:}

The authors declared that this study has received no financial support

\section{Author Contributions:}

Idea/Concept/Design: B.A.Ç, L.Ç. Data Collection and/or Processing: B.A.Ç, L.Ç. Analysis and/or Interpretation: L.Ç., B.A.Ç Literature Review: B.A.Ç, L.Ç. Writing the Article: B.A.Ç, L.Ç. Critical Review: B.A.Ç, L.Ç. Approval: L.Ç., B.A.Ç

\section{References}

Akkaya, B., Kayalıdere, U. A. ., \& Tabak, A. (2019). Endüstriyel Alanda Üretim Yapan Firmaların Örgütsel Çevikliği ile Firma Yöneticilerinin Sahip Olduğu Dinamik Yetenekler Arasındaki İlişki: Manisa Organize Sanayi Bölgesinde (MOSB) Faaliyet Gösteren Firmalar Üzerine Bir Araştırma. Yeni Nesil Girişimcilik ve Ekonomi, 19-54.

Akkaya, B., \& Tabak, A. (2018). Örgütsel Çeviklik Ölçeğinin Türkçeye Uyarlanması: Geçerlik ve Güvenirlik Çalışması. İş ve İnsan Dergisi, 5(2), 185-206. https:/ / doi.org/10.18394/iid.439184

Al-Ansari, Y., Altalib, M., \& Sardoh, M. (2013). Technology Orientation, Innovation and Business Performance: A Study of Dubai SMEs. The International Technology Management Review, 3(1), 1. https://doi.org/10.2991/itmr.2013.3.1.1

Babakus, E., \& Mangold, W. G. (1992). Adapting the SERVQUAL scale to hospital services: an empirical investigation. In Health services research (Vol. 26, Issue 6, pp. 767-786). http://www.ncbi.nlm.nih.gov/pubmed/1737708\%0Ahttp://www.pubmedcentral.nih.gov/article render.fcgi?artid=PMC1069855

Bagozzi, R. P., \& Yi, Y. (1988). On the evaluation of structural equation models. Journal of the Academy of Marketing Science, 16(1), 74-94. https://doi.org/10.1007/BF02723327 
Baki, B., \& Serdar, D. (2020a). Sanayï 4.0 olgunluk düzeyïnïn değerlendïrilmesïne yönelik çok krïterlï bïr yaklaşım: lojïstik sektörü uygulaması. Hacettepe Üniversitesi İktisadi ve İdari Bilimler Fakültesi Dergisi, 38(4), 655-693.

Baki, B., \& Serdar, D. (2020b). Sanayï 4.0 olgunluk modelï uygulamaları üzerïne lïteratür ïncelemesï. Kafkas Üniversitesi İktisadi ve İdari Bilimler Fakültesi KAÜi̇̇BFD, 11(22), 766-787.

Becker, J., Knackstedt, R., \& Pöppelbuß, J. (2009). Developing Maturity Models for I.T. Management. Business \& Information Systems Engineering, 1(3), 213-222. https://doi.org/10.1007/s12599-0090044-5

Blatz, F., Bulander, R., \& Dietel, M. (2018). Maturity Model of Digitization for SMEs. 2018 IEEE International Conference on Engineering, Technology and Innovation, ICE/ITMC 2018 Proceedings, (2004), 1-9. https:/ / doi.org/10.1109/ICE.2018.8436251

Bokša, M., Šaroch, S., \& Bokšová, J. (2020). Digitalization of SMEs. International Advances in Economic Research, 26(2), 175-177. https://doi.org/10.1007/s11294-020-09777-1

Bouranta, N., Chitiris, L., \& Paravantis, J. (2009). The relationship between internal and external service quality. International Journal of Contemporary Hospitality Management, 21(3), 275-293. https:/ / doi.org/10.1108/09596110910948297

Büyüközkan, G., \& Güler, M. (2020). Analysis of companies' digital maturity by hesitant fuzzy linguistic MCDM methods. Journal of Intelligent \& Fuzzy Systems, 38(1), 1119-1132

Coşkun, M. Ş. (2019). Örgütsel Bilgi Paylaşimi Ve Örgütsel Çevikliğin Rekabet Avantaji Üzerine Etkisi. Marmara Üniversitesi.

Çetinkaya, F. F., \& Akkoca, Y. (2021). Stratejik Liderlik İle Örgütsel Çeviklik Arasındaki İlişkide Örgütsel İletişimin Aracı Rolü. Mehmet Akif Ersoy Üniversitesi İktisadi Ve İdari Bilimler Fakültesi Dergisi, 8(1), 66-84.

Dombrowski, U., \& Ritcher, T. (2018). The Lean Production System 4.0 Framework - enhancing Lean Methods. In Springer Nature Switzerland (Vol. 536). Springer International Publishing. https://doi.org/10.1007/978-3-319-99707-0

Ekuobase, G. O., \& Olutayo, V. A. (2016). Study of Information and Communication Technology (ICT) maturity and value: The relationship. Egyptian Informatics Journal, 17(3), 239-249. https://doi.org/10.1016/j.eij.2015.12.001

Eller, R., Alford, P., Kallmünzer, A., \& Peters, M. (2020). Antecedents, consequences, and challenges of small and medium-sized enterprise digitalization. Journal of Business Research, 112(March), 119127. https:// doi.org/10.1016/j.jbusres.2020.03.004

European Commission. (2020). Digital Economy and Society Index (DESI) - Integration of digital technology. 16. https://ec.europa.eu/digital-single-market/en/integration-digital-technologyenterprises

Eryılmaz, M. (2020). Örgütlerde Dijitalizasyon ve Ardılları Üzerine Bir Tartışma. In N. Rüzgar (Ed.), İşletme Yönetimi. Ankara: Nobel Akademik Yayıncılık.

Fornell, C., \& Larcker, D. F. (1981). Evaluating Structural Equation Models with Unobservable Variables and Measurement Error. American Marketing Association, 18(1), 39-50. https://doi.org/http://www.jstor.org

Freitas Junior, J. C. da S., Gastaud Maçada, A. C., Brinkhues, R. A., \& Montesdioca, G. Z. (2016). Digital capabilities as key to digital business performance. Twenty-Second Americas Conference on Information Systems.

Gao, P., Zhang, J., Gong, Y., \& Li, H. (2020). Effects of technical I.T. capabilities on organizational agility: The moderating role of I.T. business spanning capability. Industrial Management and Data Systems, 120(5), 941-961. https:/ / doi.org/10.1108/IMDS-08-2019-0433

Gartner. (2020). Gartner.com.

Ghobakhloo, M., \& Ching, N. T. (2019). Adoption of digital technologies of smart manufacturing in SMEs. Journal of Industrial Information Integration, 16(June), 100107. https://doi.org/10.1016/j.jii.2019.100107 
Guo, H., Yang, Z., Huang, R., \& Guo, A. (2020). The digitalization and public crisis responses of small and medium enterprises: Implications from a COVID-19 survey. Frontiers of Business Research in China, 14(1), 1-25. https://doi.org/10.1186/s11782-020-00087-1

Haffke, I., Kalgovas, B., \& Benlian, A. (2016). The role of the CIO and the CDO in an Organization's Digital Transformation. 2016 International Conference on Information Systems, ICIS 2016, (December).

Hair, Joe F., Ringle, C. M., \& Sarstedt, M. (2011). PLS-SEM: Indeed a silver bullet. Journal of Marketing Theory and Practice, 19(2), 139-152. https:// doi.org/10.2753/MTP1069-6679190202

Hair, Joseph F., C. Black, W., Babin, B. J., \& Anderson, R. E. (2014). Multivariate Data Analysis, 7th Edition. In Decision Support Systems (Vol. 38). Pearson, London.

Hair, Joseph F., Ringle, C. M., \& Sarstedt, M. (2013). Partial Least Squares Structural Equation Modeling: Rigorous Applications, Better Results and Higher Acceptance. Long Range Planning, 46(1-2), 1-12. https:// doi.org/10.1016/j.lrp.2013.01.001

Hair Jr, J., Hult, G. T., Ringle, C., \& Sarstedt, M. (2016). A Primer on Partial Least Squares Structural Equation Modeling (PLS-SEM) - Joseph F. Hair, Jr., G. Tomas M. Hult, Christian Ringle, Marko Sarstedt. In Sage.

Hulland, J. (1999). Use of partial least squares (PLS) in strategic management research: a review of four recent studies. Strategic Management Journal, 20(2), 195-204. https://doi.org/10.1002/(SICI)10970266(199902)20:2<195::AID-SMJ13>3.0.CO;2-7

Işık, M. (2020). KOBİ'lerde Sosyal Sermayenin Stratejik Çevikliğe Etkisi. İzmir İktisat Dergisi, 35(1), 187200. https://doi.org/10.24988/ije.202035114

İmamoğlu, S. Z., İnce, H., \& Türkcan, H. (2021). The Effect of Industry 4.0 Implementations on Organizational Agility: A Conceptual Study. Atatürk Üniversitesi İktisadi ve İdari Bilimler Dergisi, 103-122.

Jafvert, A., \& Gustafsson, C. P. (2019). Digital Transformation in Digitally Mature Organisations: Managers' perspectives on challenges in progressing in digital maturity. Lund University School of Economics and Management.

Khin, S., \& Ho, T. C. F. (2019). Digital technology, digital capability and organizational performance: A mediating role of digital innovation. International Journal of Innovation Science, 11(2), 177-195. https://doi.org/10.1108/IJIS-08-2018-0083

Koçyiğit, Y., \& Akkaya, B. (2020). The Role of Organizational Flexibility in Organizational Agility: A Research on SMEs. Business Management and Strategy, 11(1), 110. https://doi.org/10.5296/bms.v11i1.16867

Kohli, R., \& Grover, V. (2008). Business value of I.T.: An essay on expanding research directions to keep up with the times. Journal of the Association for Information Systems, 9(1), 23-39. https://doi.org/10.17705/1jais.00147

Levallet, N., \& Chan, Y. E. (2018). Role of digital capabilities in unleashing the power of managerial improvisation. MIS Quarterly Executive, 17(1), 4-21.

Lonial, S. C., \& Carter, R. E. (2015). The impact of organizational orientations on medium and small firm performance: A resource-based perspective. Journal of Small Business Management, 53(1), 94-113. https://doi.org/10.1111/jsbm.12054

Mahmood, M. A., \& Soon, S. K. (1991). A Comprehensive Model for Measuring the Potential Impact of Information Technology on Organizational Strategic Variables. In Decision Sciences (Vol. 22, Issue 4, pp. 869-897). https:// doi.org/10.1111/j.1540-5915.1991.tb00368.x

Muller, P., Robin, N., Jessie, W., Schroder, J., Braun, H., Becker, L. S., ... Cooney, T. (2019). Annual Report on European SMEs 2018/2019 - Research \& Development and Innovation by SMEs. https://doi.org/10.2826/500457

Niemand, T., Rigtering, J. P. C., Kallmünzer, A., Kraus, S., \& Maalaoui, A. (2020). Digitalization in the financial industry: A contingency approach of entrepreneurial orientation and strategic vision on digitalization. European Management Journal, (xxxx). https://doi.org/10.1016/j.emj.2020.04.008

North, K., Aramburu, N., Lorenzo, O., \& Rego, A. Z. (2019). Digital maturity and growth of SMEs : a survey of firms in the Basque country (Spain). IFKAD 2019, (June), 1-18. Matera, Italy. 
Nuroğlu, E., \& Nuroğlu, H. H. (2018). Türkiye Ve Almanya'nın Sanayide Dijital Dönüşümü: Yol Haritaları Ve Şirketlerin Karşılaştırması. Süleyman Demirel Üniversitesi İktisadi ve İdari Bilimler Fakültesi Dergisi, 23, 1537-1560.

Özçelik, T. Ö., Erkollar, A., \& Cebeci, H. İ. (2018). Bir İmalat İşletmesi için Endüstri 4.0 (Dijital) Olgunluk Seviyesi Belirleme Uygulaması. In 5th International Management Information Systems Conference. Ankara.

Özeroğlu, E. (2019). Vizyoner Liderliğin Örgütsel Çeviklik Üzerine Etkisi; İstanbul İli Beylikdüzü İlçesinde Özel Hastanelerde Bir Uygulama [ISTANBUL GELIŞìM ÜNIVERSITTESİ]. http:/ /acikerisim.gelisim.edu.tr/xmlui/handle/11363/1564\#sthash.C8KiWRRd.dpbs

Özmen, Ö. N. T., Eriş, E. D., \& Süral Özer, P. (2020). Dijital lïderlik çalışmalarına bïr bakış. Süleyman Demirel Üniversitesi İktisadi ve İdari Bilimler Fakültesi Dergisi, 25(1), 57-69.

Pakdemirli, B. (2019). Dijital Dönüşüm ve Ekonomik Büyüme. Adıyaman Üniversitesi Sosyal Bilimler Enstitüsü Dergisi, 12(32), 666-694.

Ravichandran, T. (2018). Exploring the relationships between IT competence, innovation capacity and organizational agility. Journal of Strategic Information Systems, 27(1), 22-42. https://doi.org/10.1016/j.jsis.2017.07.002

Rettig, C. (2007). The Trouble with Enterprise Software. MITSloan Management, 49(1).

Rindova, V. P. (2001). Rindova VP, Kotha S 2001 --- Continuous morphing-Competing through dynamic capabilities, form, and function. AMJ.pdf. In Academy of Management Journal (Vol. 44, Issue 6, pp. 1263-1280).

Roberts, N., \& Grover, V. (2012). Leveraging information technology infrastructure to facilitate a firm's customer agility and competitive activity: An empirical investigation. In Journal of Management Information Systems (Vol. 28, Issue 4, pp. 231-270). https:// doi.org/10.2753/MIS0742-1222280409

Rojko, A. (2017). Industry 4.0 concept: Background and overview. International Journal of Interactive Mobile Technologies, 11(5).

Sağbaş, A., \& Gülseren, A. (2019). Endüstri 4 . 0 Perspektifinde Sanayide Dijital Dönüşüm ve Dijital Olgunluk Seviyesinin Değerlendirilmesi. European Journal of Engineering and Applied Sciences, 2(2), 1-5.

Sağbaş, M., \& İnce, H. (2015). Tedarik Zinciri Yönetiminde Bilgi Teknolojileri, Çeviklik Ve Entegrasyonun Operasyonel Ve Finansal Performansa Etkisi. Uluslararası Hakemli Beşeri Ve Akademik Bilimler Dergisi, 4(14).

Sağır, M., \& Gönülölmez, A. (2019). Yapısal Sermaye ve Insan Sermayesïnïn Işletme Performansına Etkilerï: Örgütsel Çevikliğin Aracılık Rolü. Mehmet Akif Ersoy Üniversitesi Sosyal Bilimler Enstitüsü Dergisi, 11(27), 58-77.

Sambamurthy, Bharadwaj, \& Grover. (2003). Shaping Agility through Digital Options: Reconceptualizing the Role of Information Technology in Contemporary Firms. MIS Quarterly, 27(2), 237. https:// doi.org/10.2307/30036530

Sanchez, R. O. N. (1995). Strategic Flexibility in Product Competition Author ( s ): Ron Sanchez Source: Strategic Management Journal, Vol .16, Special Issue: Technological Transformation and the New Competitive Landscape (Summer , 1995), pp . 135-159 Published by : Wiley S. Strategic Management Journal, 16(Special Issue: Technological Transformation and the New Competitive Landscape), 135159.

Savic, D. (2019). From Digitization, through Digitalization, to Digital Transformation. Online Searcher, (January), 37-39.

Sharifi, H., \& Zhang, Z. (1999). Methodology for achieving agility in manufacturing organisations: an introduction. International Journal of Production Economics, 62(1), 7-22. https://doi.org/10.1016/S0925-5273(98)00217-5

Tariq, A. T., Mad Lazim, H., \& Iteng, R. (2019). The Moderating Effect of Technology Orientation on the Relationship Between Product Innovation, Process Innovation, Organizational Learning Capability and SME's Performance. SSRN Electronic Journal, 7(9), 24-35. 
TÜİK. (2019a). Küçük ve Orta Büyüklükteki Girişim İstatistikleri, 2019. https://tuikweb.tuik.gov.tr/PreHaberBultenleri.do?id=37548\#: :text=KOBİ'ler $2019 \quad$ yilında toplam,değerin D’ünü oluşturdu.

TÜİK. (2019b). Girişimlerde Bilişim Teknolojileri Kullanım Araştırması, 2019. https:/ / data.tuik.gov.tr/Bulten/Index?p=Girisimlerde-Bilisim-Teknolojileri-KullanimArastirmasi-2019-30573

TÜİK. (2020). Girişimlerde Bilişim Teknolojileri Kullanım Araştırması, 2020. https:/ / data.tuik.gov.tr/Bulten/Index?p=Girisimlerde-Bilisim-Teknolojileri-KullanimArastirmasi-2020-33677

Uğurlu, Ö. Y., Çolakoğlu, E., \& Öztosun, E. (2019). Stratejik Çevikliğin Firma Performansına Etkisi: Üretim İşletmelerinde Bir Araştırma. İş ve İnsan Dergisi, 6(1), 93-106.

Ulas, D. (2019). Digital Transformation Process and SMEs. 3rd World Conference on Technology, Innovation and Entrepreneurship, 158, 662-671. Elsevier B.V.

Ustaoğlu, N. (2019). A Maturity Model For Digital Transformation. Sabancı University.

Ustasüleyman, T. (2008). Çevikliğin İşletme Performansina Etkisine Yönelik Yapisal Bir Model Önerisi. Gazi Üniversitesi İktisadi Ve İdari Bilimler Fakültesi Dergisi 10, 10(2), 161-178.

Williams, C., Schallmo, D., Lang, K., \& Boardman, L. (2019). Digital Maturity Models for SMEs: A Systematic Literature Review. ISPIM Conference Proceedings, (June), 1-15.

Wong, K. K. K.-K. (2013). 28/05 - Partial Least Squares Structural Equation Modeling (PLS-SEM) Techniques Using SmartPLS. Marketing Bulletin, 24(1), 1-32.

Wroblewski, J. (2018). Digitalization and Firm Performance: Are Digitally Mature Firms Outperforming Their Peers? (Lund university school of economics and management digitalization). Lund university school of economics and management digitalization.

Yiğitol, B., Güleş, H. K., \& Sarı, T. (2020). Endüstri 4.0 Dönüşüm Sürecinde, KOBİlerin Teknoloji Seviyelerinin Belirlenmesi : Konya İmalat Sanayi Örneği. Int. J. Adv. Eng. Pure Sci., 32(3), 320-332. https://doi.org/10.7240/jeps.665375

Yıldırım, B. (2020). İŞLETMELERDE DİJiTAL DÖNÜŞÜM SÜRECİ: NITTEL BİR ARAŞTIRMA. Ekonomi Maliye İşletme Dergisi, 3(2), 204-223.

Zhou, K. Z., \& Wu, F. (2010). Technological capability, flexibility and product innovation. Strategic Management Journal, 31, 547-561 
Appendix - 1

\begin{tabular}{|c|c|c|c|}
\hline Sub-Factors & Code & Ölçeğin Türkçe Adaptasyonu & Original Scale \\
\hline \multirow{4}{*}{$\begin{array}{l}\text { Customer } \\
\text { Experience }\end{array}$} & DM1 & $\begin{array}{l}\text { Müşterilerimizi daha iyi anlamak için bilişim } \\
\text { teknolojilerini kullanıyoruz }\end{array}$ & $\begin{array}{l}\text { We are using digital technologies (such as analytics, social } \\
\text { media, mobile, and embedded devices) to understand our } \\
\text { customers better. }\end{array}$ \\
\hline & DM2 & $\begin{array}{l}\text { Ürün ve hizmetlerimizi pazarlamak için dijital } \\
\text { kanalları kullanıyoruz (dijital kanallar = kurumsal web } \\
\text { sitesi, mobil uygulamalar, sosyal medya, online } \\
\text { reklam çalışmaları, e-posta pazarlama) }\end{array}$ & $\begin{array}{l}\text { We use digital channels to market our products and } \\
\text { services. (digital channels= online, social media, mobile) }\end{array}$ \\
\hline & DM3 & $\begin{array}{l}\text { Ürün veya hizmetlerimizi dijital kanallar üzerinden } \\
\text { satıyoruz }\end{array}$ & $\begin{array}{l}\text { We sell our products or services online through digital } \\
\text { channels (digital channels= online, social media, mobile) }\end{array}$ \\
\hline & DM4 & $\begin{array}{l}\text { Müssteri hizmetleri sunmak için dijital kanalları } \\
\text { kullanıyoruz }\end{array}$ & We use digital channels to provide customer service \\
\hline \multirow{4}{*}{$\begin{array}{l}\text { Operational } \\
\text { Processes }\end{array}$} & DM5 & $\begin{array}{l}\text { Bilişim, müşteriyle iletişim ve işletmeyle ilgili süreçleri } \\
\text { yeni şekillerde birleştirmemize imkan vermektedir } \\
\text { (süreç=yapılan işler, iş faaliyetleri) }\end{array}$ & $\begin{array}{l}\text { Technology is allowing us to link customer-facing and } \\
\text { operational processes in new ways }\end{array}$ \\
\hline & DM6 & $\begin{array}{l}\text { Temel iş faaliyetlerimiz otomasyona dayalı olarak } \\
\text { gerçekleştirilmektedir (otomasyon= işlerin insan } \\
\text { aracılığı olmadan büyük ölçüde otomatik işleyen araç } \\
\text { ve ekipmanla yapılması) }\end{array}$ & $\begin{array}{l}\text { Our core processes are automated (automated= operated } \\
\text { largely by automatic equipment) }\end{array}$ \\
\hline & DM7 & $\begin{array}{l}\text { Temel iş faaliyetlerimizin farklı departmanlar, birimler } \\
\text { ve sistemler boyunca bilişim aracılığıyla } \\
\text { bütünleştirilmesi ve birbirleriyle uyumlu çalışması } \\
\text { hedeflenmektedir }\end{array}$ & $\begin{array}{l}\text { We have an integrated view of key operational and } \\
\text { customer information (integrated view=close and } \\
\text { seamless coordination between several departments, } \\
\text { groups, organizations, systems) }\end{array}$ \\
\hline & DM8 & $\begin{array}{l}\text { Firmamızla ilgili daha iyi kararlar vermek iş analitiği } \\
\text { kullanmaktayız }\end{array}$ & We use analytics to make better operational decisions \\
\hline \multirow[t]{2}{*}{ Business Models } & DM9 & $\begin{array}{l}\text { Mevcut ürün ve hizmetlerimizin performansını veya } \\
\text { katma değerini artırmak için bilişim teknolojilerini } \\
\text { kullanmaktayız }\end{array}$ & $\begin{array}{l}\text { We use digital technologies to increase the performance or } \\
\text { added value of our existing products and services }\end{array}$ \\
\hline & DM10 & $\begin{array}{l}\text { Bilişim teknolojilerine dayalı yeni iş modelleri } \\
\text { geliştirdik }\end{array}$ & $\begin{array}{l}\text { We have launched new business models based on digital } \\
\text { technologies }\end{array}$ \\
\hline \multirow{5}{*}{$\begin{array}{l}\text { Customer } \\
\text { Responsiveness }\end{array}$} & OA1 & Müşteri ihtiyaçlarını tespit etmek & Identifying customer needs \\
\hline & OA2 & $\begin{array}{l}\text { Ürünleri/hizmetleri müşteri ihtiyaçlarına göre } \\
\text { uyarlamak }\end{array}$ & Tailoring products/services to customer needs \\
\hline & OA3 & $\begin{array}{l}\text { Firma tarafından ürün/hizmet sunulmayan müşteri } \\
\text { gruplarını belirlemek }\end{array}$ & Identifying customer groups not served by the firm \\
\hline & OA4 & Müşterilerin hizmet taleplerine cevap vermek & Responding to customer service requests \\
\hline & OA5 & Müşterilere ürünler/hizmetlerle ilgili bilgi vermek & Providing information to customers \\
\hline \multirow{7}{*}{$\begin{array}{l}\text { Operational } \\
\text { Flexibility }\end{array}$} & OA6 & $\begin{array}{l}\text { İşletme içi süreçleri entegre etmek (entegre etmek= } \\
\text { birbirleriyle uyumlu şekilde çalışabilmesi için } \\
\text { bütünleştirmek) }\end{array}$ & Integrating internal processes \\
\hline & OA7 & $\begin{array}{l}\text { Tedarik zinciri boyunca tüm birimlerin bütünleşik ve } \\
\text { uyumlu bir şekilde çalışmasını sağlamak }\end{array}$ & Integrating across its supply chain \\
\hline & OA8 & $\begin{array}{l}\text { İş süreçlerinin esnekliğini artırmak (esneklik=kısa bir } \\
\text { süre içinde çok az bir maliyet ve çabayla değişebilme } \\
\text { veya değişime uyum sağlayabilme yeteneği) }\end{array}$ & Enhancing business process flexibility \\
\hline & OA9 & Ürün geliştirme hızını artırmak & Increasing the speed of product development \\
\hline & OA10 & Ürün teslimat hızını artırmak & Increasing the speed of product delivery \\
\hline & OA11 & Lojistik faaliyetlerinin hızını artırmak & Increasing the speed of logistics activities \\
\hline & OA12 & $\begin{array}{l}\text { İş fırsatlarına ve tehditlerine cevap verme hızını } \\
\text { artırmak }\end{array}$ & $\begin{array}{l}\text { Increasing the speed of responding to business } \\
\text { opportunities and threats }\end{array}$ \\
\hline \multirow{4}{*}{$\begin{array}{l}\text { Strategic } \\
\text { Flexibility }\end{array}$} & OA13 & Yeni pazarlar belirlemek & Identifying new markets \\
\hline & OA14 & Yeni pazarlara girmek & Entering new markets \\
\hline & OA15 & $\begin{array}{l}\text { İşletmenin faaliyet alanını yeniden değerlendirmek ve } \\
\text { gerekli durumlarda farklı şekilde tanımlamak }\end{array}$ & Redefining the scope of its business \\
\hline & OA16 & Rakiplerin ürün ve hizmet stratejilerine cevap vermek & Responding to competitors' product and service strategies \\
\hline \multirow{5}{*}{$\begin{array}{l}\text { Firm } \\
\text { Performance }\end{array}$} & P1 & Genel karlılık düzeyi & Net profit \\
\hline & $\mathrm{P} 2$ & Temel faaliyetlerden elde edilen net gelir & Cash flow from operations \\
\hline & P3 & Genel finansal durum & Profit to revenue ratio \\
\hline & $\mathrm{P} 4$ & Pazar payındaki artış (son 3 yıllık dönemde) & Market share gain over the last three years \\
\hline & P5 & Gelir düzeyindeki artış (son 3 yıllık dönem) & Revenue growth over the last three years \\
\hline
\end{tabular}

